\title{
Expert System For Cupping Treatment Using Case Based Reasoning Method
}

\author{
Evi Dewi Sri Mulyani" ${ }^{* 1}$, Rahadi Deli Saputra ${ }^{2}$, Rais Mujahidul Haq ${ }^{3}$ \\ 1,2,3Program Studi Teknik Informatika, STMIK Tasikmalaya \\ E-mail: ${ }^{* 1}$ eviajadech@gmail.com, ${ }^{2}$ rahadidelisaputra@gmail.com, ${ }^{3}$ raiskun99@gmail.com
}

\begin{abstract}
Cupping is one of the methods of treatment taught by Rasulullah SAW (thibbun nabawi) which can be believed to be a cure because it is sourced from revelations that are certain, divine powers with the perfection of reason. Rasulullah SAW said: "Every disease has a cure. So if the drug is about an illness, the disease will be cured with the permission of Allah SWT. (HR. Muslim), cupping is the best choice for treatment, because it is cheap, lawful, safe, practical and follows the sunnah of Rasulullah SAW. If cupping is done properly and correctly, according to medical rules. With the limited knowledge and memory of the therapist in determining the location of the cupping point can be an error because if there is a new symptom or with a new disease that has never been overcome by a therapist becomes one of the obstacles in determining the location of the cupping point quickly and accurately. so the need for the application of an expert system that can facilitate the cupping therapists to determine the location of the cupping point to patients precisely and quickly. Expert system that will be created using a case based reasoning method. The implementation of the system uses the PHP programming language and MYSQL database. With an expert system that uses the case-based reasoning method of cupping treatment can determine the cupping point precisely in accordance with the symptoms that are inputted to be processed into output in the form of solutions to overcome the disease by displaying conclusions in the form of cupping points so as to facilitate the services performed by therapist.
\end{abstract}

Keywords - Expert system, Determining Cupping Points, Case Based Reasoning

\section{INTRODUCTION}

Disease is a cause of disturbance in the human body and all of that is not foreign to society, these are all obstacles that are often faced by society. All humans already know that their bodies have health problems, but most people do not know the diseases that are attacking their bodies and how to treat them. So that to find out which disease is attacking the human body, it takes an expert who understands health problems.

Cupping is one of the methods of treatment taught by Rasulullah SAW (thibbun nabawi) whose healing can be believed because it comes from revelations that are definite, divine power with perfection of reason. Rasulullah SAW said: "Every disease has a cure. So if the drug is about a disease, the disease will be cured with the permission of Allah SWT. " (HR. Muslim), cupping is the best choice for treatment, because it is cheap, lawful, safe, practical and follows the sunnah of the Prophet Muhammad. If cupping is done properly and correctly, according to medical rules.

Based on the results of an interview with a cupping expert named Ustadz Jamal Kamaludin that there is a limited knowledge and memory of the therapist in determining the point of cupping so that errors can occur because if there is a new symptom or a new disease that has never been treated by a therapist, it becomes one of them. The obstacle in determining the point of cupping is because the therapist has to consult his expert again so that it takes a very long time.

Therefore, researchers built a system as a tool to assist therapists in providing knowledge about cupping points and can also be used as a consulting tool, it is hoped that this system can work more quickly and precisely than humans.

This study uses a journal related to CBR (Case Based Reasoning) because, Case Based Reasoning is a method of solving problems by remembering the same or similar events that have happened in the past then using that knowledge or information to solve new problems, or in words others solve the problem by facing solutions that have been used in the past ${ }^{[1]}$. Case Based 
Reasoning works by studying previous cases collected in a General Knowledge which will later be compared with new cases, Case Based Reasoning has four stages, namely Retrieve, Reuse, Revise and Retain, this method is very powerful for creating expert systems that made into a learning machine, which will automatically add or revise knowledge automatically into general knowledge ${ }^{[2]}$. Case Based Reasoning (CBR) between old and new cases uses the concept of similarity and the best solution is taken based on Bayes probability calculations. Based on the experiments that have been carried out, this expert system application for the diagnosis of dengue fever reaches an accuracy rate of $92 \%$. This value is considered quite satisfactory because it meets the minimum classification determined by WHO, and is able to reach the average ability of doctors in Indonesia in diagnosing dengue fever ${ }^{[3]}$.

\section{RESEARCH METHODS}

This study uses the Case Base Reasoning method, using the Modified Waterfall system development method beginning with the requirements definition analysis stage, namely needs analysis and knowledge engineering. Followed by system and software design, namely process design and interface design. Then implementation and unit testing. After that comes the final stage, namely the integration of system testing using the black box test method. This application is web based, php as programming language and sql as database.

This research refers to the research conducted by Bagus Imam, the research that has been done, produced a new software (software) about the application of experts in diagnosing human diseases with cupping treatment ${ }^{[4]}$. The next study used the Case Base Reasoning method compiled by Nor Cholis in his thesis entitled "Application of Expert System for Medical Diagnosis of Circulatory System Diseases Using the Case Based Reasoning Method" [5]. In this study, it discusses the medical diagnosis of circulatory system diseases. And the resulting software (software) in the diagnosis of diseases of the human circulatory system using artificial neural networks with the Case Based Reasoning method.

An expert system is a system that tries to adopt human knowledge to a computer, so that the computer can solve problems as is usually done by experts. A good expert system is designed to solve a certain problem by imitating the work of the experts. With this expert system, awampun people can solve quite complicated problems which actually can only be solved with the help of experts ${ }^{[6]}$.

CPC case-based reasoning is a knowledge-based approach to studying and solving problems based on past experiences. Past experiences are collected and stored in a place called "Case Base". Case base is a collection of cases that have occurred ${ }^{[7]}$.

In producing a solution to a problem using the PBB methodology, the PBB must carry out several stages of the process where the PBB must look for the similarity of a new case to a stored case, or when there are changes to the solution of a case. The stages of the process that occur in PBB require four 4 stages, namely:

- RETRIEVE is to find back the same or most similar cases as new cases

- REUSE is to reuse information and knowledge from the case base to solve new case problems (this process is called "solution transfer").

- REVISE is to revise or improve the proposed solution.

RETAIN is a store of experience for solving future problems on a case basis. Therefore the success of an expert system lies in the knowledge and how to process this knowledge so that it can be drawn conclusions ${ }^{[8]}$

\section{RESULTS AND DISCUSSION}

\section{A. Analysis and Definition Of Requirements \\ 3.1 Needs Analysis}

The process of gathering needs is intensified and focused, especially on software. In order to understand the nature of the program being built, the software engineer (analyst) must understand the information domain, behavior and interface required. Needs Analysis is a stage in building an expert system. 
Table 1. List of Symptoms

\begin{tabular}{|c|l|c|}
\hline Kode & \multicolumn{1}{|c|}{ Gejala } & Bobot \\
\hline G01 & Nyeri Perut Kanan Atas & 5 \\
\hline G02 & Nyeri Pada Pinggang Atas & 3 \\
\hline G03 & Nyeri Perut Kiri Atas & 3 \\
\hline G04 & Nyeri Di Ulu Hati & 5 \\
\hline G05 & Nyeri Pada Telinga & 3 \\
\hline$\ldots$ & $\ldots$ & $\ldots$ \\
\hline G86 & Nyeri Di Kepala Belakang & 5 \\
\hline
\end{tabular}

The table above shows the symptoms that arise, there are 86 symptoms that can be analyzed by the author along with the total weight of each symptom.

Table 2. List of Diseases

\begin{tabular}{|c|l|}
\hline Kode & \multicolumn{1}{|c|}{ Nama Penyakit } \\
\hline P01 & Spondilosis Servikal \\
\hline P02 & Artritis Sendi Perifer \\
\hline P03 & Gout (Asam Urat) \\
\hline P04 & Systematic Lupus Erythematosis (Lupus) \\
\hline P05 & Rheumatoid Disease (Rematik) \\
\hline$\ldots$ & $\ldots$ \\
\hline P30 & Migrain (Sakit Kepala Sebelah) \\
\hline
\end{tabular}

The table above is a list of diseases that have become the conclusion of this expert system. From the symptom and disease data, the information obtained can be simplified with a decision tree whose contents are the relation or relationship between several symptoms to produce a production rule. The decision tree for a cupping expert system can be seen in Figure 1 below.
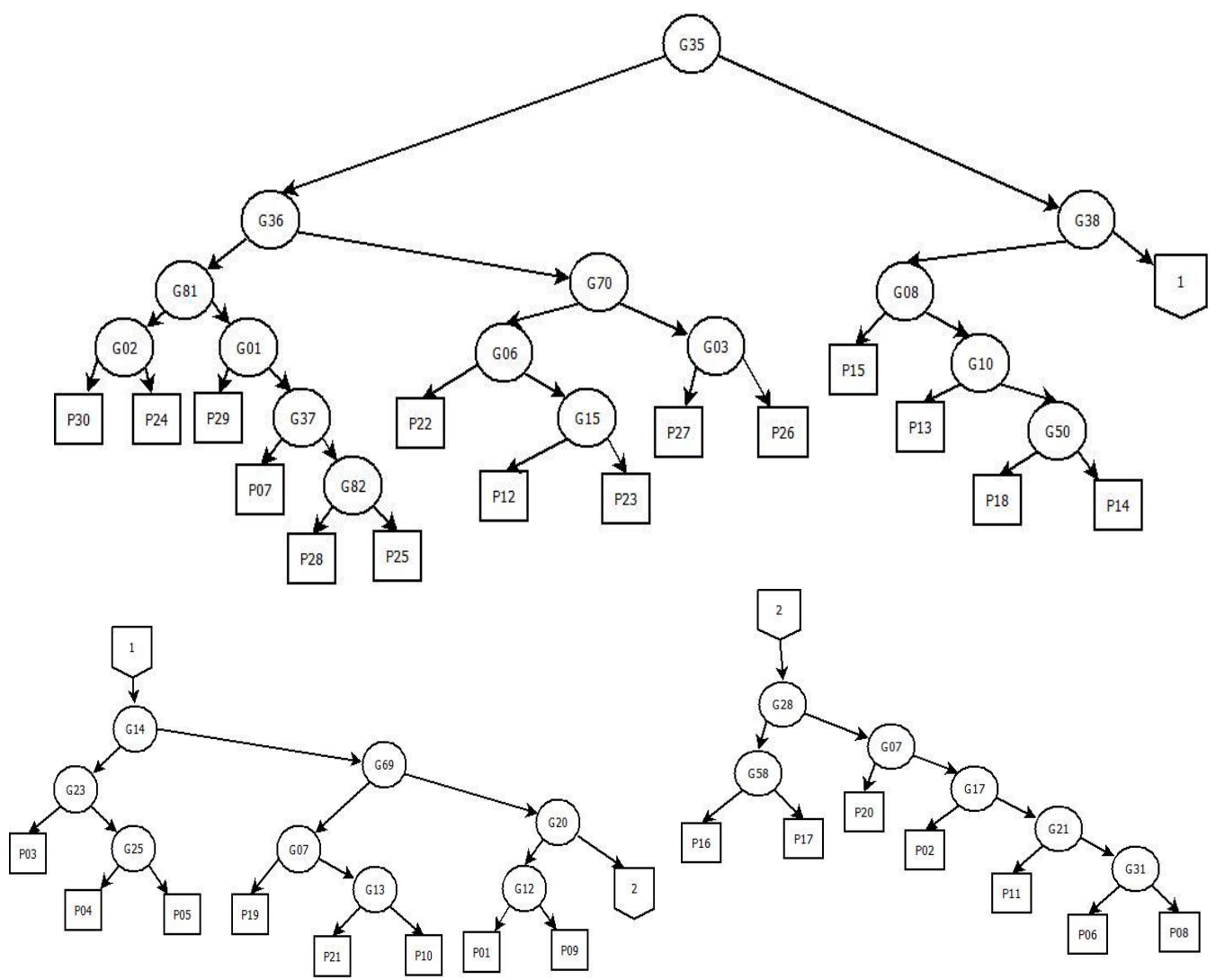

Figure 1. Decision Tree 
In table 3 below are the production rules or rules in the design of an expert cupping system.

Table 3. Production Rules Table

\begin{tabular}{|c|c|l|}
\hline No & \multicolumn{2}{|c|}{ Kaidah Produksi } \\
\hline \multirow{2}{*}{1.} & If & $\begin{array}{l}\text { Nyeri Pada Leher / Punggung Jari-Jari Tangan / Kaki Mati Rasa Pusing } \\
\text { Kejang Pada Otot Punggung / Leher }\end{array}$ \\
\cline { 2 - 3 } 2 & Then & Spondilosis Servikal \\
\hline \multirow{2}{*}{2.} & If & $\begin{array}{l}\text { Nyeri Pada Ligamen Sendi/Nyeri Pada Tulang Rawan Peradangan } \\
\text { Rematik }\end{array}$ \\
\cline { 2 - 3 } & Then & Artritis Sendi Perifer \\
\hline \multirow{2}{*}{3.} & If & $\begin{array}{l}\text { Nyeri Pada Saat Menekan/Menggerakan Persendian Sendi Memerah / } \\
\text { Terasa Panas Bengkak Pada Kaki }\end{array}$ \\
\cline { 2 - 3 } & Then & Gout (Asam Urat) \\
\hline \multirow{2}{*}{4.} & If & $\begin{array}{l}\text { Nyeri Pada Saat Menekan/Menggerakan Persendian Muncul Beberapa } \\
\text { bercak Merah Di Kulit Sering Keluar Kotoran Mata Peradangan Pada } \\
\text { Mata Susah Bernafas }\end{array}$ \\
\cline { 2 - 3 } & Then & Systematic Lupus Erythematosis (Lupus) \\
\hline \multirow{2}{*}{5.} & If & $\begin{array}{l}\text { Nyeri Pada Saat Menekan/Menggerakan Persendian Adanya Benjolan } \\
\text { Pada Ligamen Sendi Peradangan Pada Mata }\end{array}$ \\
\cline { 2 - 3 } .. & Then & Rheumatoid Disease (Rematik) \\
\hline \multirow{2}{*}{30.} & $\ldots$ & $\ldots$ \\
\cline { 2 - 3 } & If & $\begin{array}{l}\text { Mual Muntah-Muntah Nyeri Di Kepala Sebelah / Migrain Kelelahan } \\
\text { Kurang Tidur }\end{array}$ \\
\hline
\end{tabular}

The production rules in this expert system are written in an if-then (IF-THEN) form. The rule can be said to be a two-part implication relationship, namely the premise (if) and the conclusion (then). If the premise is fulfilled, the conclusion will also be true.

\subsection{Engineering Knowledge}

Knowledge engineering for determining the cupping point begins with making the flow of decisions, collecting criteria data and rule data. The flow in the expert system, namely Retrieve, in this process expert experts through cupping assistants (selected assistants as data input assistants for diseases, symptoms, causes, point images and suggestions) collect data for determining disease and cupping points. Reuse in this second stage the system will look for problems by searching the database to look for pre-existing symptoms that match and have the most dominant similarities with existing problems. In this review, a comparison will be made to find out whether there has been a condition similar to that before. Revise, after the reuse stage, the system will provide suggestions for determining the disease and the cupping point of the old case. These suggestions will be revised according to new cases. Treatment for new cases. Retain, in the end the problem type data in the new case will be saved into the database to be used again in the next cases that have similarities in it.

Measurement of Case Similarity (Similarity), In looking for cases that have similarities to new cases, each new case will be equated with all on a case basis with its factor factors, in this study the symptoms are the only factor to measure the similarity of cases. From the cased based reasoning (CBR) system, reasoning is the calculation similarity between new cases - user input and previous cases stored in the base case. Cases dealing with qualitative and quantitative parameters are called features or attributes. The CBR algorithm calculates the similarity between cases based on the feature-value pairs between new and each historical cases. The following is a general method of calculating local similarity that we will use in this study ${ }^{[5]}$.

Formula

$$
\begin{gathered}
\mathrm{S} 1 * \mathrm{~W} 1+\mathrm{S} 2 * \mathrm{~W} 2+\ldots+ \\
\mathrm{Sn} * \mathrm{Wn} \\
\mathrm{W} 1+\mathrm{W} 2+\ldots+\mathrm{Wn}
\end{gathered}
$$


Note:

(S) imilarity: the similarity value is 1 (same) and 0 (different)

$(\mathrm{W})=$ wight (given weight)

Table 4. Example of Calculation

\begin{tabular}{|c|c|c|c|c|}
\hline No & Penyakit & $\begin{array}{c}\text { Gejala } \\
\text { Kasus \& } \\
\text { Bobot }\end{array}$ & $\begin{array}{c}\text { Gejala Yang Di } \\
\text { Pilih Pasien } \\
\text { (Cocok) }\end{array}$ & $\begin{array}{c}\text { Presentase } \\
\text { Kecocokan }\end{array}$ \\
\hline \multirow{3}{*}{1} & & {$[\mathrm{G} 04][5]$} & {$[\mathrm{G} 04][5]$} & $7 / 10 * 100=70 \%$ \\
& {$[\mathrm{P} 27]$ Magh } & {$[\mathrm{G} 70][1]$} & {$[\mathrm{G} 70][1]$} & \\
& {$[\mathrm{G} 35][1]$} & {$[\mathrm{G} 03][3]$} & {$[\mathrm{G} 35][1]$} & $1 / 15 * 100=$ \\
& & {$[\mathrm{G} 01][5]$} & & $6,67 \%$ \\
& & {$[\mathrm{G} 35][1]$} & {$[\mathrm{G} 35][1]$} & \\
\hline
\end{tabular}

The following calculations for ulcer disease:

$=\overline{7=} \quad 0,7 * 100=70 \%$

So the results of the consultation based on the calculation of the highest similarity, namely $70 \%$, namely magh disease.

\section{B. System Planning}

System design is the activity of designing or designing a system, which contains the operational steps in the data processing process and procedures to support system operation.

System design in making this cupping treatment expert system uses UML (Unified Modeling Language) diagrams. UML (Unified Modeling Language) is a modeling language for object-oriented paradigm systems or software. Modeling is actually used to simplify complex problems in such a way that they are easier to learn and understand.

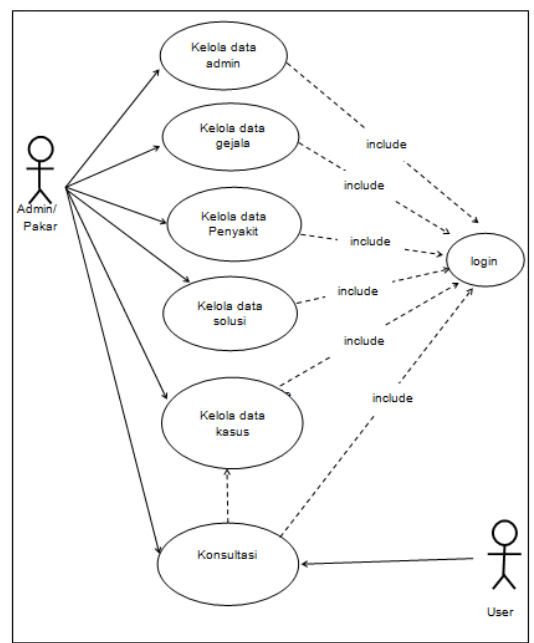

Figure 2. Use Case Diagram of Expert System for cupping treatment

\section{Program Implementation}

Figure 3 is the consultation menu which is the core application menu of this cupping treatment expert system. The consultation menu serves to consult the user with the application to determine the disease and location of the cupping point. In the user consultation menu, the symptoms felt by the patient will be provided. 


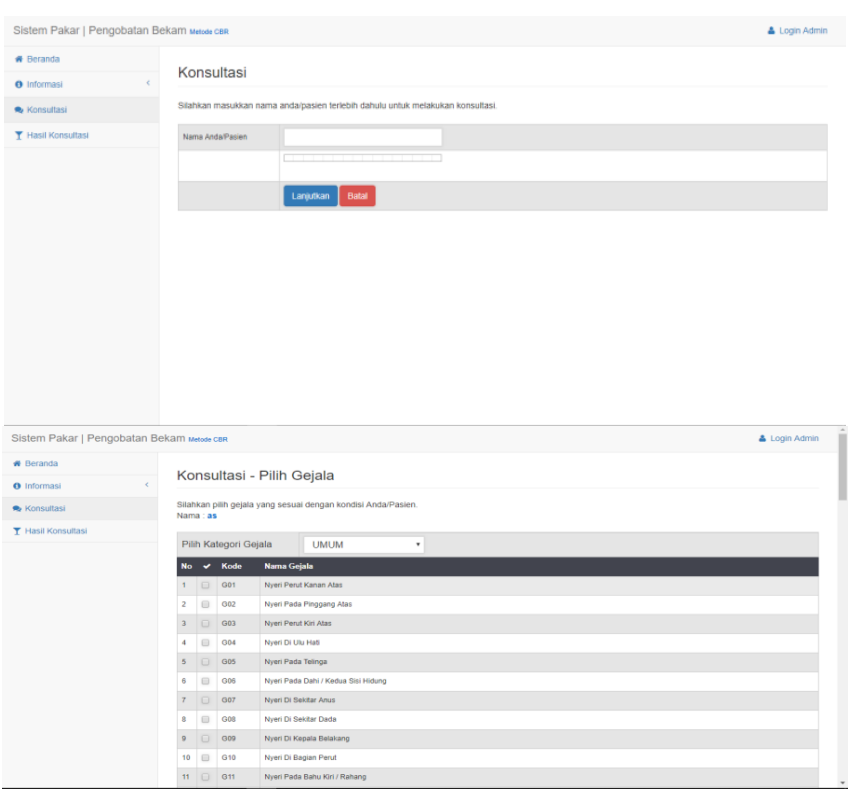

Figure 3. Consultation Menu Display

After completing several questions, the system will provide output information about the solution in the form of what disease is suffered and the solution through Figure 4 below.

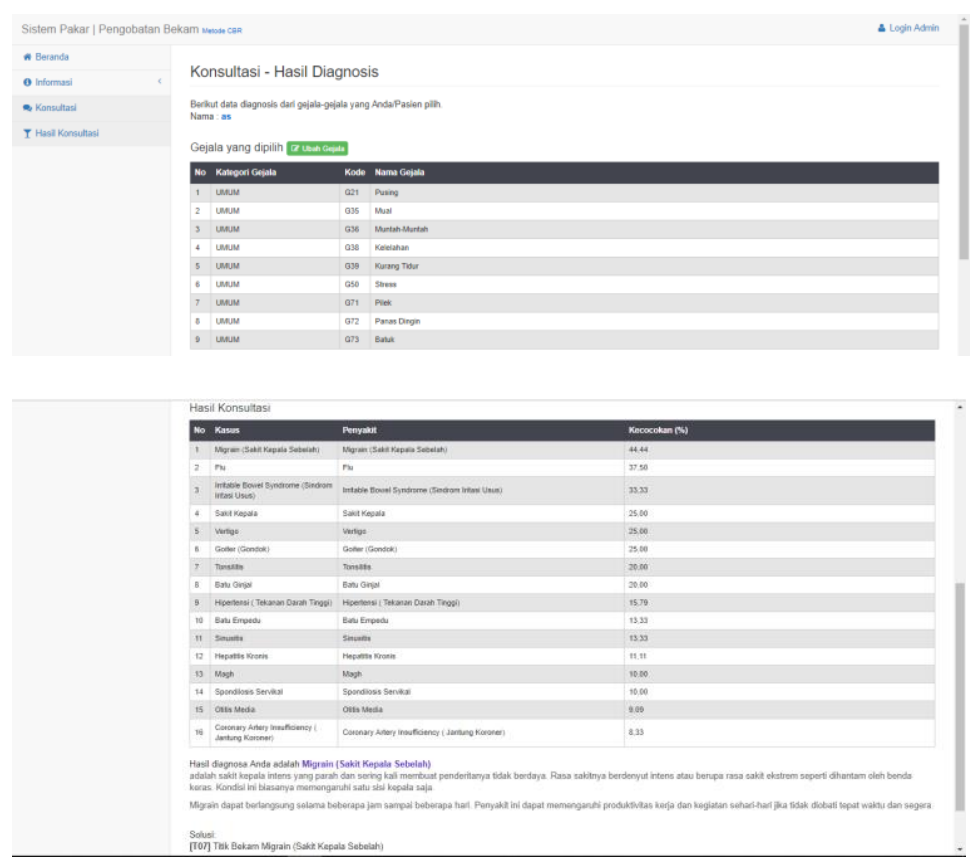

Figure 4. Display of Consultation Result Menu

\section{Testing}

System testing is one of the stages in the process of building this expert system in order to get a match between the design and the program results. It is intended that implementation runs in accordance with the final goal. The type of test used is black box testing. In black box testing, the method of testing is only done by running or executing a unit or module, then observing whether the results of the unit are in accordance with the desired process. 
Table 5. Testing Consultation Menu

\begin{tabular}{|c|c|c|c|}
\hline \multicolumn{4}{|c|}{ Pengujian Fungsi Tombol Konsultasi } \\
\hline Data Masukan & Yang Diharapkan & Pengamatan & Kesimpulan \\
\hline $\begin{array}{l}\text { Menuliskan nama terlebih } \\
\text { dahulu dengan benar }\end{array}$ & $\begin{array}{l}\text { Menampilkan form } \\
\text { gejala-gejala }\end{array}$ & Form gejala-gejala & $\begin{array}{l}{[\sqrt{ }] \text { Diterima }} \\
{[\text { ] Ditolak }}\end{array}$ \\
\hline $\begin{array}{l}\text { Menuliskan nama dengan } \\
\text { salah }\end{array}$ & $\begin{array}{l}\text { Maaf ada kesalahan } \\
\text { pengisian data / } \\
\text { tidak bisa masuk ke } \\
\text { form selanjutnya }\end{array}$ & $\begin{array}{l}\text { Maaf ada kesalahan } \\
\text { pengisian data }\end{array}$ & $\begin{array}{l}{[\sqrt{ }] \text { Diterima }} \\
{[\text { ] Ditolak }}\end{array}$ \\
\hline $\begin{array}{l}\text { Memilih Gejala kemudian } \\
\text { simpan gejala, lalu lanjutkan } \\
\text { hasil diagnosis }\end{array}$ & $\begin{array}{l}\text { Menampilkan hasil } \\
\text { diagnosis / solusi }\end{array}$ & $\begin{array}{l}\text { Menampilkan hasil } \\
\text { diagnosis / solusi }\end{array}$ & $\begin{array}{l}{[\sqrt{ }] \text { Diterima }} \\
{[\text { ] Ditolak }}\end{array}$ \\
\hline $\begin{array}{l}\text { Memilih gejala tapi tidak di } \\
\text { simpan }\end{array}$ & $\begin{array}{lr}\text { Maka akan } & \text { tampil } \\
\text { kembali } & \text { form } \\
\text { gejala-gejala } & \end{array}$ & $\begin{array}{l}\text { Kembali ke form } \\
\text { gejala }\end{array}$ & $\begin{array}{l}{[\sqrt{ }] \text { Diterima }} \\
{[\text { ] Ditolak }}\end{array}$ \\
\hline
\end{tabular}

From the results of black box testing on the validation and functionality of the application, it can be concluded that each form responds as expected.

\section{CONCLUSION}

With an expert system that uses the case-based reasoning method of cupping treatment, this cupping treatment can determine the point of cupping precisely according to the inputted symptoms to be processed into output in the form of a solution to overcome the disease by displaying a conclusion in the form of an image of cupping points so that it makes the service easier. by a therapist .. This expert system can be implemented in any cupping place provided there is someone who understands how to cupping or can be called a therapist.

\section{SUGGESTED}

This system can be developed again on the information on the symptom data, the disease, and the solution to be more and more and can be developed into mobile devices such as android and iOs.

\section{REFERENCES}

[1] Vandika, A. Y., \& Cucus, A. (2017). Sistem Deteksi Awal Penyakit TBC Dengan Metode CBR. Jurnal Informatika, 17(2), 54-60.

[2] Ernawati, E. (2017). Sistem Pakar Diagnosa Penyakit Pencernaan Manusia Menggunakan Metode Case Based Reasoning. Sistemasi, 6(2), 35-44.

[3] Jatmiko, A. D., Junaedi, D., \& Imrona, M. (2017). Analisis Dan Implementasi Sistem Pakar Dengan Metode Case Based Reasoning Dan Rule Based Reasoning (studi Kasus: Diagnosis Penyakit Demam Berdarah). eProceedings of Engineering, 4(2).

[4] SN, B. I., \& Winiarti, S. Implementasi Sistem Pakar Untuk Pengobatan Bekam Dengan Metode Case Base Reasioning (Studi Kasus: Rumah Bekam Muslimah YOGYAKARTA). Jurnal Sarjana Teknik Informatika, 2(2), 389-398.

[5] Norcholis, 2013, Aplikasi Sistem Pakar Untuk Diagnosa Medis Pada Penyakit Sistem Peredaran Darah Menggunakan Metode Case Base Reasoning, Yogyakarta : Universitas Ahmad Dahlan.

[6] Nashr, Alu, Musa, Muhammad, 2005, BEKAM Cara Pengobatan Menurut Sunnah Nabi, Pustaka imam Asy-Syafi'i, Jakarta.

[7] D. Satori and A. Komariah, Metode Penelitian Kualitatif. 2011.

[8] Mulyani, E. D. S., Agustin, Y. H., \& Nur'aeni, I. (2018). Aplikasi Pakar Untuk 
Mengidentifikasi Karakteristik Gaya Belajar Dengan Menerapkan Modalitas Vark. Jurnal VOI (Voice Of Informatics), 7(1). 